\begin{tabular}{|l|c|c|c|c|}
\hline $\begin{array}{l}\text { Cuadernos de Investigación Geográfica } \\
\text { Geographical Research Letters }\end{array}$ & 2020 & $\mathbf{N}^{\circ} 46(2)$ & pp. 395-411 & eISSN 1697-9540 \\
\hline
\end{tabular}

\title{
MAPPING THE POTENTIAL DISTRIBUTION OF FROZEN GROUND IN TUCARROYA (MONTE PERDIDO MASSIF, THE PYRENEES)
}

\author{
E. SERRANO ${ }^{1 *}$, A. PISABARRO ${ }^{1}$, J.I. LÓPEZ-MORENO ${ }^{2}$, \\ M. GÓMEZ-LENDE ${ }^{1}$, R. MARTÍN-MORENO ${ }^{3}, \mathrm{I} \mathrm{RICO}^{4}$

\begin{abstract}
${ }^{1}$ Dept. Geography, GIR PANGEA, University of Valladolid, Spain. ${ }^{2}$ Dept. of Geoenvironmental Processes and Global Change, Instituto Pirenaico de Ecología, Consejo Superior de Investigaciones Científicas (IPE-CSIC), Campus de Aula Dei, P.O. Box 13.034, 50080 Zaragoza, Spain.

${ }^{3}$ Dept. Didácticas Específicas, Universidad Autónoma de Madrid; Spain. ${ }^{4}$ Dept. of Geography, Prehistory and Archaeology, University of the Basque Country, Spain.
\end{abstract}

\begin{abstract}
This paper shows the creation of a map of frozen ground potential for the Tucarroya valley in Ordesa National Park. To create this map, it was necessary to combine the identified landforms associated to the presence of frozen ground by fieldwork, ground temperature data continuously recorded during two years by automatic loggers, a Basal Temperature of Snow (BTS) survey, and predictor variables derived from a high resolution Digital Elevation Model (DEM). Four environments have been differentiated: unfrozen ground, seasonal frozen ground, possible permafrost and probable permafrost. The map confirms a very limited variety and extension of permafrost, above $2700 \mathrm{~m}$ a.s.l. on gentle and shadowed slopes. Seasonal frozen ground is the most common thermal regime, as it can be developed above $2500 \mathrm{~m}$ a.s.l. Snow-pack duration and thickness tightly control the duration of frozen ground and the freezing-thawing cycles. Frost activity and unfrozen ground is restricted from 2570 to $2750 \mathrm{~m}$ a.s.l.
\end{abstract}

Cartografía de la distribución potencial del suelo helado en Tucarroya (Macizo de Monte Perdido, Pirineos)

RESUMEN. Este trabajo describe la metodología utilizada para cartografiar los suelos potencialmente helados en el valle de Tucarroya, en el Parque Nacional de Ordesa. Para cartografiar las formas asociadas a la presencia de hielo se combinó trabajo de campo, datos térmicos procedentes de sensores automáticos de temperatura del suelo y mediciones de la base del manto de nieve (BTS), así como variables predictivas obtenidas de un Modelo Digital de Elevaciones (MDE). La cartografía diferencia cuatro ambientes, suelo no congelado con actividad de la helada, suelos helados estacionales, permafrost posible y permafrost probable. El mapa revela una extensión del permafrost muy limitada, con escasez de formas asociadas. Solo se ha detectado por encima de los $2700 \mathrm{~m}$ de altitud en ambientes 
topográficos favorables, pendientes suaves y protegidos de la radiación solar. Los suelos helados estacionales son los ambientes más comunes y se desarrollan por encima de los $2500 \mathrm{~m}$ s.n.m., mientras los suelos no congelados, pero con heladas solo están presentes entre los 2570 y los 2750 m de altitud en laderas que reciben elevada radiación solar.

Key words: Frozen ground, permafrost, mapping, Pyrenees.

Palabras clave: suelos helados, permafrost, cartografía, Pirineos.

Recibido:8 November 2019

Aceptado: 31 December 2019

*Corresponding author: Enrique Serrano, Dept. of Geography, GIR-PANGEA, University of Valladolid, Spain. E-mail address: serranoe@fyl.uva.es

\section{Introduction}

Knowledge of the frozen ground distribution and its typology leads to an improved understanding of the geomorphology, hydrology and ecology of cold environments. The presence of ice in the ground is closely linked to vegetation, soil formation or degradation and changes in the biotopes. Permafrost is commonly mapped in high mountain areas to observe the potential distribution of mountain permafrost (Gruber and Haeberli, 2009; Haeberli et al., 2010). Different modelling techniques have been applied to map permafrost in the world's main mountains (Hegimbottom et al., 2002; Boeckli et al., 2012). On small spatial scales the existence of active rock glaciers are the main indicator of permafrost. However, on larger scales and in places where rock glaciers do not exist other elements can be used, though with greater uncertainty and inaccuracy in the delineation of existing frozen grounds. Therefore, different indicators based on fieldwork, monitoring and remote sensing permit detailed maps of frozen ground distribution to be made in relatively small areas (Zhang et al., 2014).

Maps of frozen ground are a useful tool not only to know the mountain cryosphere and to understand geomorphic processes related to the active layer and landform distribution. They also lead to an understanding of the thermal setting of habitats and geosystems, as well as the ice and frost activity to take into consideration in ecological studies in high mountain areas. Their relationships with species living at high altitude, such as extremophiles, mammals, birds or plants, are determined by seasonal or permanent frozen grounds. The snow distribution and snow-cover persistence during summer is also influenced by frozen ground. Frozen ground maps are evidently of interest to geoecological and ecological studies, and particularly in natural protected areas (NPA) where knowledge, protection and conservation are priority aims.

Tucarroya Cirque belong to the Ordesa-Monte Perdido National Park, the second National Park to be declared in Spain (1918), which was extended to include 
the summits and Tucarroya cirque in 1982. The study area has also been included in the wider Unesco Biosphere Reserve of Ordesa-Vignemale (M\&B Program) since 1977, and was declared World Heritage Site by Unesco in 1997 (Martínez de Pisón et al., 2001). It is therefore a territory of natural heritage value, and managers, policy-makers and authorities need to know about its habitats, ecosystems and geosystems. The cryosphere is a key element at higher altitudes and a symbol of landscape and nature conservation in the Pyrenees. The cryosphere of the National Park includes four glaciers, including the Monte Perdido Glacier, the second largest in the Pyrenees, and more than a dozen of ice caves, among them the famous Casteret ice cave (Martínez de Pisón and Arenillas, 1988; García-Ruiz and Martí-Bono, 2001, López-Moreno et al., 2016, 2019; Rico et al., 2017; Serrano et al., 2018b). Nevertheless, frozen grounds are the most widespread element of the cryosphere, after the winter snow-cover.

Periglacial environments and their dynamics have been studied in the Pyrenees mainly in relation to the mapping of landform, and particularly focused on rock glaciers (Serrano et al., 1999; 2001, 2009; 2018a; Oliva et al., 2016, 2018). Maps of permafrost distribution were made in Posets Massif, differentiating among sporadic, discontinuous and continuous permafrost (Serrano et al., 2001; Lugon et al., 2004). The spatial distribution of mountain permafrost was obtained around the Aneto peak by means of the Inverse Distance Weighting (IDW) interpolation model (Chueca and Julián, 2010), and thermal and permafrost maps have been made in the Alba-Maladeta, Infiernos Massif and La Paúl Cirque (González-Garcia, 2013; Serrano et al., 2019). The entire Pyrenees was mapped on a scale 1:500,000 also using an IDW interpolation model (Serrano et al., 2009). The map differentiated between possible and probable permafrost and showed the potential occurrence of permafrost environments in all massifs higher than $3000 \mathrm{~m}$ a.s.l. In the Pyrenees attention has been paid to mountain permafrost and its distribution, but not to the presence of seasonally frozen ground (SFG), nor its distribution and relationships with freeze and thaw processes in the periglacial and paraglacial high mountain environment.

The aim of this work is to know the distribution of periglacial environments and to map the Tucarroya area in detail such that frozen ground, SFG and permanently frozen ground, can be represented. The map integrates information on periglacial landforms and processes, ground thermal regimes, medium annual and winter ground temperatures and topoclimatic variables such as altitude, slope, aspect, and potential radiation. This is the first detailed scale map on frozen ground in the National Park and it is the first map to include SFG.

\section{Study site}

The Tucarroya valley is located in the central Pyrenees between the Monte-PerdidoMarboré range (Monte Perdido Peak, $3295 \mathrm{~m}$ a.s.l.) to the south and the Astazou range to the north, both over $3000 \mathrm{~m}$ a.s.l. (Fig. 1). It is a broad hanging valley located between 2450 to $3335 \mathrm{~m}$ a.s.l. (Fig. 1A). 
Pleistocene glaciers have shaped the valley to form a wide glacial cirque with overdeepening basin, glacial bars, and frontal and lateral moraines (Nicolás, 1981; García-Ruiz and Martí-Bono, 2001; Martín-Moreno, 2006; López-Moreno et al., 2016). The northern area, around the Tuvarroya Lake, was free of ice before $12.7 \mathrm{ka}$ BP (Valero et al., 2013; García-Ruiz et al., 2014; Leunda et al., 2017), but the central and southern areas, included the north-facing slopes of Monte Perdido and Marboré, was occupied by glaciers during the middle Holocene (García-Ruiz et al., 2014) and the Little Ice Age, when several periods of advance or surges happened (Nicolás, 1981; Martínez de Pisón and Arenillas, 1988; Serrano and Martín-Moreno, 2018; Oliva et al., 2018). Periglacial studies have been carried on Monte perdido and Tucarroya, mainly focused on patterned ground (Barrère, 1952; Boyé, 1952; Nicolás, 1981; García-Ruiz and Martí-Bono, 2001; Martín-Moreno, 2006).

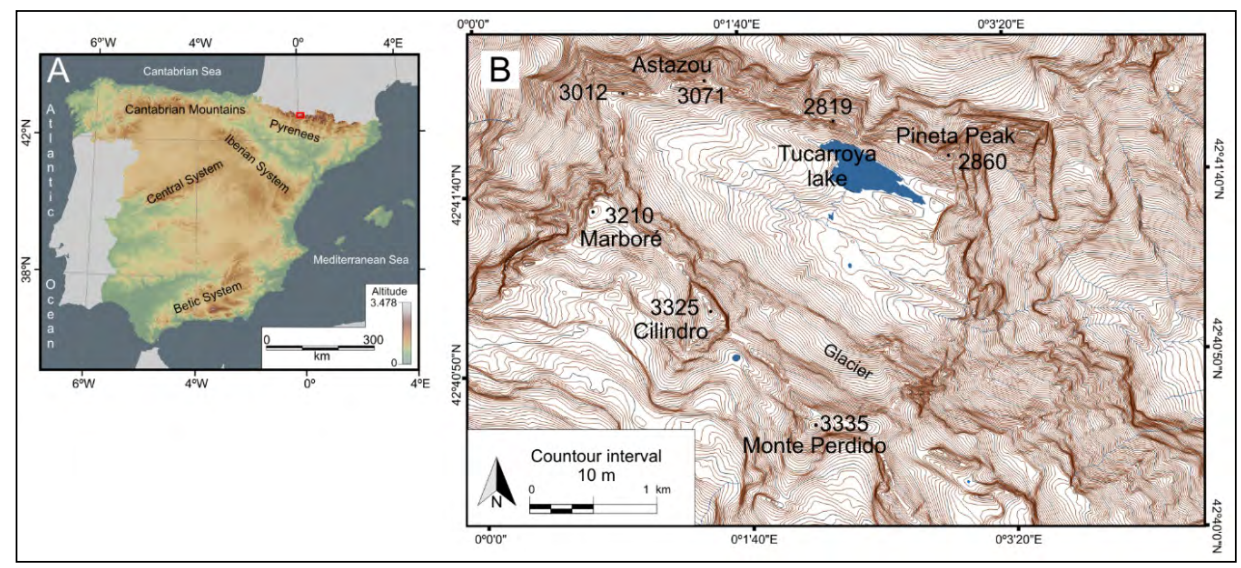

Figure 1. Location of the Tucarroya. A. In the Iberian Peninsula. B. topographic map of the study area.

The climate at the front of the Monte Perdido Glacier (2780 m a.s.1.) is defined by an annual precipitation estimated to exceed $2000 \mathrm{~mm} \mathrm{yr}^{-1}$ and an average summer temperature of $7.3^{\circ} \mathrm{C}$ (López-Moreno et al., 2019). The snowpack lasts from October-November to late May-early July, and scattered snow-patches remain throughout the year on its slopes. López-Moreno et al., (2019) have estimated the $0^{\circ} \mathrm{C}$ isotherm at $\sim 2950 \mathrm{~m}$ a.s.l. and reported a deep snowpack over the glacier and surrounding areas.

The structural relief is made up of a succession of overturned folds and thrust of southern vergence, the Monte Perdido Thrust. The substrate is formed by alternating limestones, marls, sandstones and dolomites (Fig. 2) of the Cretaceous age (Ríos et al., 1989; García Ruiz and Martí Bono, 2001). 




Figure 2. DEM (A) and Lithological sketch (B) of the Tucarroya área. 


\section{Methods}

The geomorphological map of this paper shows periglacial landforms mapped in the field by the aid of colour orthorectified images corresponding to sheet 146-4 of the Spanish topographic map $(1: 25,000)$ (fot-06-5944, 5945, 5946, 5947) (PNOA, 2015). Besides, this type of mapping can be combined with information of periglacial thermal processes to define landsystems (Evans et al. 2017). The altitudinal thermal classification of landforms (González-García, 2013; Serrano et al., 2019) permits us to considerate as permafrost or SFG indicators four of the mapped landforms (Table 1).

Table 1. Periglacial processes and landforms analyzed in Tucarroya cirque.

\begin{tabular}{|c|c|c|c|c|}
\hline Processes & Landforms & $\begin{array}{c}\text { Altitude } \\
\mathbf{m}\end{array}$ & Orientation & Indicators \\
\hline \multirow{3}{*}{ Frost cracking } & $\begin{array}{c}\text { Debris talus and } \\
\text { cones }\end{array}$ & $3040-2555$ & $\mathrm{~N}, \mathrm{~S}$ & Freeze-thaw \\
\cline { 2 - 5 } & Crest and ridges & $2700-3300$ & -- & Freeze-thaw \\
\hline \multirow{2}{*}{ Nivation } & Nival pavements & $2950-2500$ & -- & Freeze-thaw \\
\cline { 2 - 5 } & Nivokarst landforms & $3100-2500$ & -- & No frost \\
\hline \multirow{2}{*}{$\begin{array}{c}\text { Mass movement } \\
\text { Gelifluction and } \\
\text { frozen ground } \\
\text { creep }\end{array}$} & Debris flow & $2700-2500$ & $\mathrm{~S}$ & No frost \\
\cline { 2 - 5 } & Terracettes & $2650-2490$ & $\mathrm{~N}, \mathrm{~S}, \mathrm{E}$ & Freeze-thaw \\
\hline \multirow{2}{*}{\begin{tabular}{c} 
Cryoturbation \\
\cline { 2 - 5 }
\end{tabular}} & Protalus lobes & $2900-2850$ & $\mathrm{~N}, \mathrm{NE}, \mathrm{NW}, \mathrm{SE}$ & SFG \\
\cline { 2 - 5 } & Patterned grounds & $2790-2530$ & Flat areas & Permafrost \\
\hline
\end{tabular}

Surface ground temperatures (GTS) and the ground thermal regime were monitored by means of 18 continuous data-loggers (Ibuttons DS1922L and DS1921G) placed at depths of between 2 and $\sim 10 \mathrm{~cm}$ between 2014 and 2016. Dataloggers were distributed from $2585 \mathrm{~m}$ a.s.l. to $3075 \mathrm{~m}$ a.s.l., and recorded data at four-hourly intervals within a resolution of $\pm 0.5^{\circ} \mathrm{C}$. The occurrence of permafrost or seasonally frozen ground (SFG) was estimated using mean annual ground temperature (MAGT) and mean winter ground temperature (MWGT). MAGT and MWGT allow to differentiate areas with permafrost from other areas with SFG o without frozen ground but with freeze and thaw alternance. They indicate SFG or permafrost when the MAGT is $<0^{\circ} \mathrm{C}$ throughout the year (van Everdingen, 1978), and when the MWGT is between $<-2^{\circ} \mathrm{C}$ and $<-6^{\circ} \mathrm{C}$.

The MWGT can be complemented with Basal Termperatures of Snow (BTS) measurements to define homogeneous thermal behavior areas for mapping (Lambiel, 2006; Lambiel and Pieracci, 2008). 49 readings taken at the ground-snow interface were recorded in March 2016. The MWGT of 67 sites were collected from BTS and datalogger measurements. Both GTS and BTS data were used to represent the thermal 
distribution on the ground by means of the ground thermal map of Tucarroya (Serrano et al. 2020).

The most common permafrost maps are based on a spatial classification of permafrost (continuous, discontinuous and sporadic) but also in the degree of certainty about its existence (possible and probable, Table 2) and combine field observations and semiempirical models (Keller, 1992; Hoetzle et al., 1993; Keller et al., 1998; Heginbottom, 2002; Boeckli et al., 2012; Zhang et al., 2014; Bockheim, 2015). Alpine permafrost distribution can be statistically differentiated as probable or possible permafrost (Hoetzle et al., 1993; Keller et al., 1998; Heginbottom, 2002). Modelling techniques with GIS, using predictors derived from a DEM and validated by GTS and BTS measurements permit the presence or distribution of cryogenic processes and frozen ground to be established (Keller, 1992; Hoelzle, 1996; Gruber and Hoelzle, 2001; Heginbottom, 2002; Janke, 2005; Lambiel and Pieracci, 2008; Serrano et al., 2009; González-García et al., 2014).

Table 2. Indicators of mountain frozen ground types and periglacial environments.

\begin{tabular}{|l|l|c|c|c|l|}
\hline Permafrost & $\begin{array}{l}\text { Morphogenetic } \\
\text { indicators }\end{array}$ & $\begin{array}{c}\text { MAAT } \\
{ }^{\mathbf{o}} \mathbf{C}\end{array}$ & $\begin{array}{c}\text { MAGT } \\
{ }^{\mathbf{0}} \mathbf{C}\end{array}$ & $\begin{array}{c}\text { MWGT } \\
{ }^{\mathbf{o}} \mathbf{C}\end{array}$ & Ground conditions \\
\hline Probable & $\begin{array}{l}\text { Rock glaciers } \\
\text { Protalus lobes* } \\
\text { Permanent ice } \\
\text { patches* } \\
\text { Frost mounds* }\end{array}$ & $<-6$ & -2 & $<-3$ & $\begin{array}{l}\text { North orientations } \\
\text { Flat ot gentle slopes } \\
\text { Low solar radiation }\end{array}$ \\
\hline Possible & Indicators are scarce & $<-2$ & $0 /-2$ & $<-2$ & $\begin{array}{l}\text { North orientations } \\
\text { Flat or gentle slopes } \\
\text { Debris deposits }\end{array}$ \\
\hline SFG & $\begin{array}{l}\text { Stone banked lobes* } \\
\text { Patterned ground* } \\
\text { Frost mounds* } \\
\text { Solifluction sheets* } \\
\text { Ploughing blocks }\end{array}$ & $<0$ & $1 /-2$ & $<0$ & $\begin{array}{l}\text { North orientations } \\
\text { Flat or gentle slopes } \\
\text { Low solar radiation }\end{array}$ \\
\hline
\end{tabular}

Based on Keller, 1992; Funk and Hoelzle, 1992, Hoezle et al., 1993; Hoelzle, 1996; Keller et al., 1998; Gruber and Hoelzle, 2001; Heginbottom, 2002; Delaloyé, 2004. * Indicators used in the work.

In Tucarroya, MAGT, MWGT and BTS were transformed to a continuous variable by IDW interpolation (order 3) to be able to extract the 0 and $-2^{\circ} \mathrm{C}$ isotherms of the resulting ground thermal map (Fig. 3A; Serrano et al. 2020). Landforms indicating the presence of frozen bodies such as protalus lobes, stone-banked lobes or frost mounds, were overlapped with isotherms and topoclimatic influence using ArcGIS 10.4.

The topoclimatic influence integrates data to know the effects of the topoclimatic factors (Funk and Hoelzle, 1992). These factors were extracted from a LiDAR DEM with a spatial resolution of $5 \mathrm{~m}$ provided from the Spanish Geographic Institute. The topoclimatic factors included were aspect, slope, altitude and global solar radiation $\left(\mathrm{Wh} \cdot \mathrm{m}^{-2}\right)$ for a full day in the middle of winter (February 15) by the Area Solar Radiation tool (Fig. 3B, 3C, 3D). 


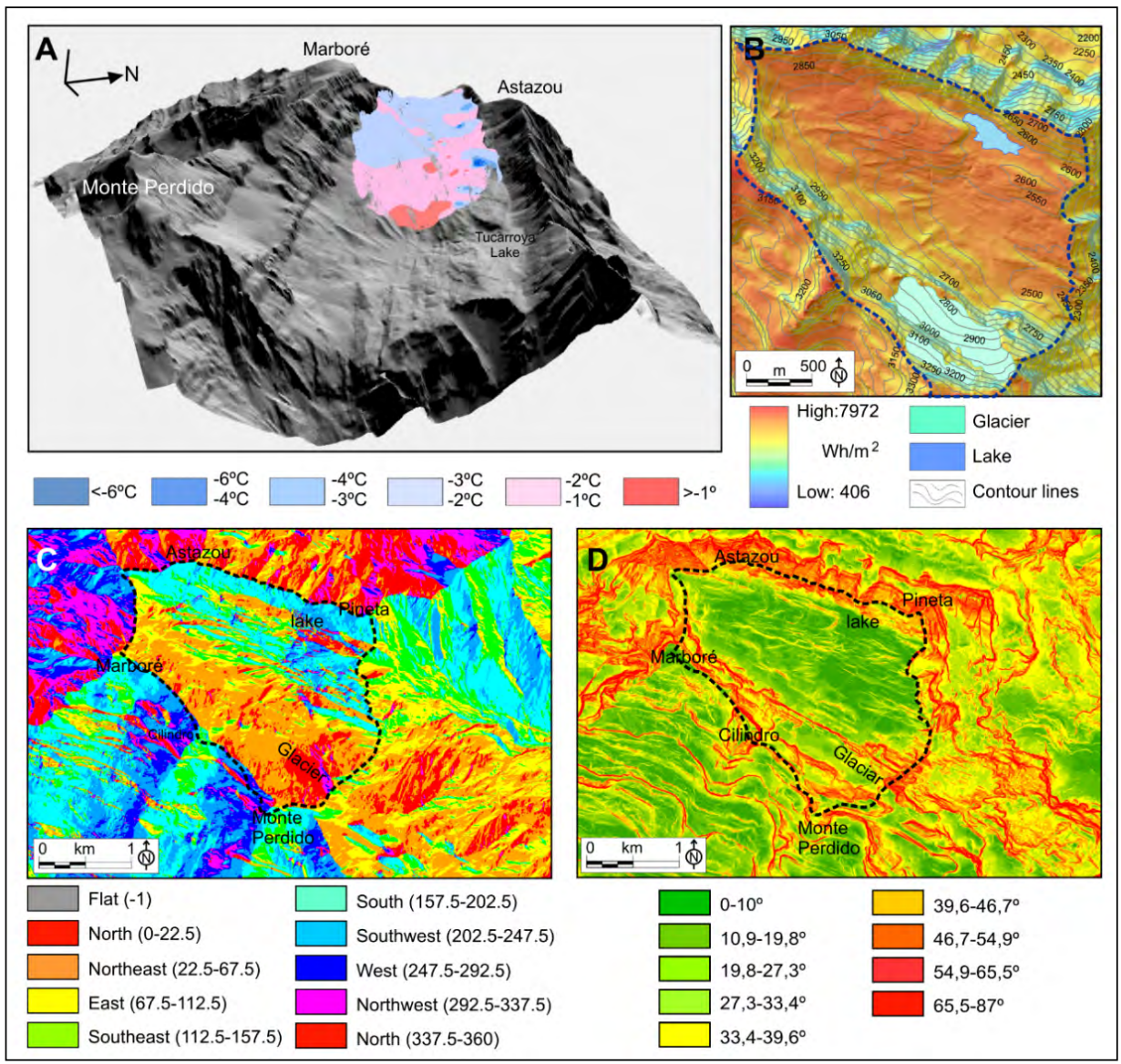

Figure 3. Ground conditions in the Tucarroya. A, Ground temperature distribution from BTS measurements. B, solar radiation map. C, aspects map. D, slopes map. Dotted line, limit of studied area.

Finally, the potential distribution of frozen grounds map was drawn through the layer overlapping.

\section{Results and discussion}

The periglacial mapped features reveal the scarcity of periglacial landforms, both in quantity, variety and extension (Fig. 4). The dominant processes -frost weathering, nivation, gelifluction and cryoturbation- do not necessarily confirm the presence of SFG or permafrost. The periglacial landforms that indicate ice activity or frozen ground in Tucarroya can be grouped into three genetic types, shown in Table 3. 




Figure 4. Location of periglacial landforms, BTS measurements, the automatic meteorological station and datalogger in Tucarroya.

Data from temperature data-loggers revealed that snow-cover lasts at least six months above $2580 \mathrm{~m}$ a.s.1., 7-8 months over $2700 \mathrm{~m}$ a.s.l., and 8.5 months over $2750 \mathrm{~m}$ a.s.l. Thus, the snow-pack is essential to insulate the ground from the air. Snow could be the main element in determining the ground thermal regime as well as a key driver of several geomorphological features such as protalus processes and gelifluction (Serrano et al., 2019). 
Table 3. Genetic types of frozen ground activity detected in the Tucarroya Cirque.

\begin{tabular}{|c|c|c|c|c|}
\hline Ice activity & Processes & Landforms & $\begin{array}{c}\text { MAGT } \\
{ }^{\circ} \mathbf{C} \\
\end{array}$ & $\begin{array}{c}\text { Altitude } \\
\text { m a.s.l. }\end{array}$ \\
\hline $\begin{array}{l}\text { Ground freeze- } \\
\text { thaw cycles }\end{array}$ & $\begin{array}{c}\text { Frost weathering } \\
\text { Frost cracking } \\
\text { Rockfall }\end{array}$ & $\begin{array}{c}\text { Debris cones } \\
\text { Debris talus }\end{array}$ & $2 /-7$ & $3040-2555$ \\
\hline \multirow{3}{*}{$\begin{array}{l}\text { SFG with ground } \\
\text { freeze-thaw cycles }\end{array}$} & \multirow{2}{*}{ Gelifluction } & Stone-banked lobes & $0 /-4$ & \multirow{3}{*}{$\begin{array}{c}3030- \\
2490\end{array}$} \\
\hline & & Terracettes & $1.5 / 6$ & \\
\hline & Cryoturbation & Patterned ground & $2 /-2$ & \\
\hline \multirow{2}{*}{$\begin{array}{l}\text { Presence of frozen } \\
\text { bodies }\end{array}$} & Cryoturbation & Frost mounds & $0 /-4$ & \multirow{2}{*}{$\begin{array}{l}2900- \\
2700\end{array}$} \\
\hline & Creep & Protalus lobe & $0 /-2$ & \\
\hline
\end{tabular}

Between the three types of ground thermal regime that define the study area (Serrano et al., 2019; Table 4), the most extensive one is the climate-controlled thermal regime, which occupies a broad part of the valley bottom and mainly on south-facing slopes. The frozen ground-controlled regime is located in the upper parts of the slopes and summit areas, always above $2650 \mathrm{~m}$ a.s.l. The ground thermal regime defines the periglacial environments represented on the map, although several of them can co-exist at the same altitudes.

Table 4. Ground thermal regimes

\begin{tabular}{|l|c|c|c|c|}
\hline \multicolumn{2}{|c|}{ Ground thermal regime type } & $\begin{array}{c}\text { Altitude } \\
\text { m }\end{array}$ & Thermal state & Processes \\
\hline $\begin{array}{l}\text { Climate } \\
\text {-controlled }\end{array}$ & $\begin{array}{c}\text { High correlation with } \\
\text { air temperature }\end{array}$ & $\begin{array}{c}3075 \\
2800\end{array}$ & $\begin{array}{c}\text { MAGT }>0^{\circ} \mathrm{C} \text {, Unfrozen ground } \\
\text { throughout the year }\end{array}$ & $\begin{array}{c}\text { Frost weathering } \\
\text { Freezing and } \\
\text { thawing }\end{array}$ \\
\hline $\begin{array}{l}\text { Snow-cover } \\
\text { controlled }\end{array}$ & $\begin{array}{c}\text { Ground insulation by } \\
\text { the snow-cover }\end{array}$ & 2785 & $\begin{array}{c}\text { Zero curtain effect } \\
0^{\circ} \mathrm{C} \text { for } 6 \text { to } 8 \text { months }\end{array}$ & $\begin{array}{c}\text { Frost weathering } \\
\text { Freezing and } \\
\text { thawing }\end{array}$ \\
\hline \multirow{2}{*}{$\begin{array}{l}\text { Frozen } \\
\text { ground- } \\
\text { controlled }\end{array}$} & $\begin{array}{c}\text { Low correlation with } \\
\text { air temperature }\end{array}$ & 3000 & $\begin{array}{c}\text { Frozen ground over 4-6 months. } \\
\text { MWGT: }-4^{\circ} \mathrm{C} /-5.9^{\circ} \mathrm{C}\end{array}$ & \multirow{2}{*}{$\begin{array}{c}\text { Permafrost } \\
\text { SFG }\end{array}$} \\
\cline { 3 - 5 } & 2675 & $\begin{array}{c}\text { Ground T }<0^{\circ} \mathrm{C}: 2-5 \text { months } * \\
\text { Short zero curtain } \text { fffect }^{*} \\
\text { MWGT: }-0.1^{\circ} \mathrm{C} /-7.5^{\circ} \mathrm{C}\end{array}$ & \\
\hline
\end{tabular}

Based on Serrano et al., 2019. * Average Monthly temperature

The map differentiates four main periglacial ground environments (Fig. 5):

- Unfrozen ground with surface frost activity. The main processes and landforms are nival, together with frost weathering, ground freeze-thaw cycles and microgelivation. The shaped landforms are debris cones and debris talus on slopes, and frost-weathered bedrock on flat areas. These types are found between $2^{\circ} \mathrm{C}$ and $-2^{\circ} \mathrm{C}$ but dominant MAGT is $>0^{\circ} \mathrm{C}$. Freeze-thaw cycles occurs mainly during autumn, before the ground is insulated by the snow-cover. The 
ground temperature depends on the snow-cover depth, working as an efficient insulator, with a zero-curtain effect (temperature is $\sim 0^{\circ} \mathrm{C}$ ) for 6 to 8 months. This ground environment extends from 2570 to $2750 \mathrm{~m}$ a.s.l. Several sites where the snow-pack is shallow due to wind blowing exhibited a high correlation between ground and air temperatures.

- Seasonally frozen ground. It is the most extended ground environment. Gelifluction and cryoturbation are the most common processes on sedimentary formations and frost weathering over subtract and walls. Processes shaping stone-banked lobes, terracettes and patterned ground are very efficient because of the combination of frost weathering and frozen ground. Correlation between ground and air temperatures is low. Ground freezes and melts every year, remaining frozen between 4 and 6 months. The MAGT has a thermal range from $2^{\circ} \mathrm{C}$ to $-4^{\circ} \mathrm{C}$ with MWGT from $-4^{\circ} \mathrm{C}$ to $-5.9^{\circ} \mathrm{C}$. Ground temperatures below $0^{\circ} \mathrm{C}$ last between 2 and 5 months. This environment extends from 2400 to $3000 \mathrm{~m}$ a.s.1., although it is more common above $2500 \mathrm{~m}$ a.s.1.

- Possible permafrost. It is located in a narrow band close to the north face of the Monte Perdido-Marboré range. Gelifluction and cryoturbation are the processes indicating frozen ground, shaping frost mounds and stone-banked lobes. These landforms are distributed from 2700 to $2900 \mathrm{~m}$ a.s.1., always on moraines and flat north-facing areas. The stone-banked lobes have a wide altitudinal range and aspects $\mathrm{N}, \mathrm{S}, \mathrm{NE}$ and SE. The ground and air temperature have a low correlation, with MAGT $<-2^{\circ} \mathrm{C}$, showing possible permafrost from $2760 \mathrm{~m}$ a.s.l. MWGT is well below $0^{\circ} \mathrm{C}$ from 2770 up to $2850 \mathrm{~m}$ a.s.l.

- Probable permafrost. It is located on north-facing slopes above $2870 \mathrm{~m}$ a.s.l., but the dominant conditions are above $2985 \mathrm{~m}$ a.s.1. Gelifluction and cryoturbation are also the main periglacial processes, together with nivation and frost-weathering. The landform indicators of frozen ground is the only protalus lobe in the area, but there also frost mound and stone-banked lobes. The protalus lobe is the only landform defined by a frozen body and creep processes located on the NE face to 2850-2900 m. Correlation between ground and air temperatures is low; the environment unit is located above the $0^{\circ} \mathrm{C}$ isotherm, MAGT is $<-4^{\circ} \mathrm{C}$ and MWGT oscillates between $-4^{\circ} \mathrm{C}$ and $-5.9^{\circ} \mathrm{C}$.

The map (Fig. 5) shows possible permafrost only above $2760 \mathrm{~m}$ a.s.l. and SFG in a broad altitudinal range from 2650 to $3075 \mathrm{~m}$ a.s.1. The landforms associated to the presence of permafrost are very scarce and occupy small areas. Environments with permafrost are relegated to the highest parts of the cirques, at over $2750 \mathrm{~m}$ and shaded aspects, although steep slopes, ridges and mountain passes are not favourable to the development of permafrost (Haeberli et al., 2010; Magnin et al., 2017). On the flat or very gentle slope areas with high radiation, permafrost is absent. Thus, permafrost conditions are concentrated in north-facing areas (Fig. 5). 


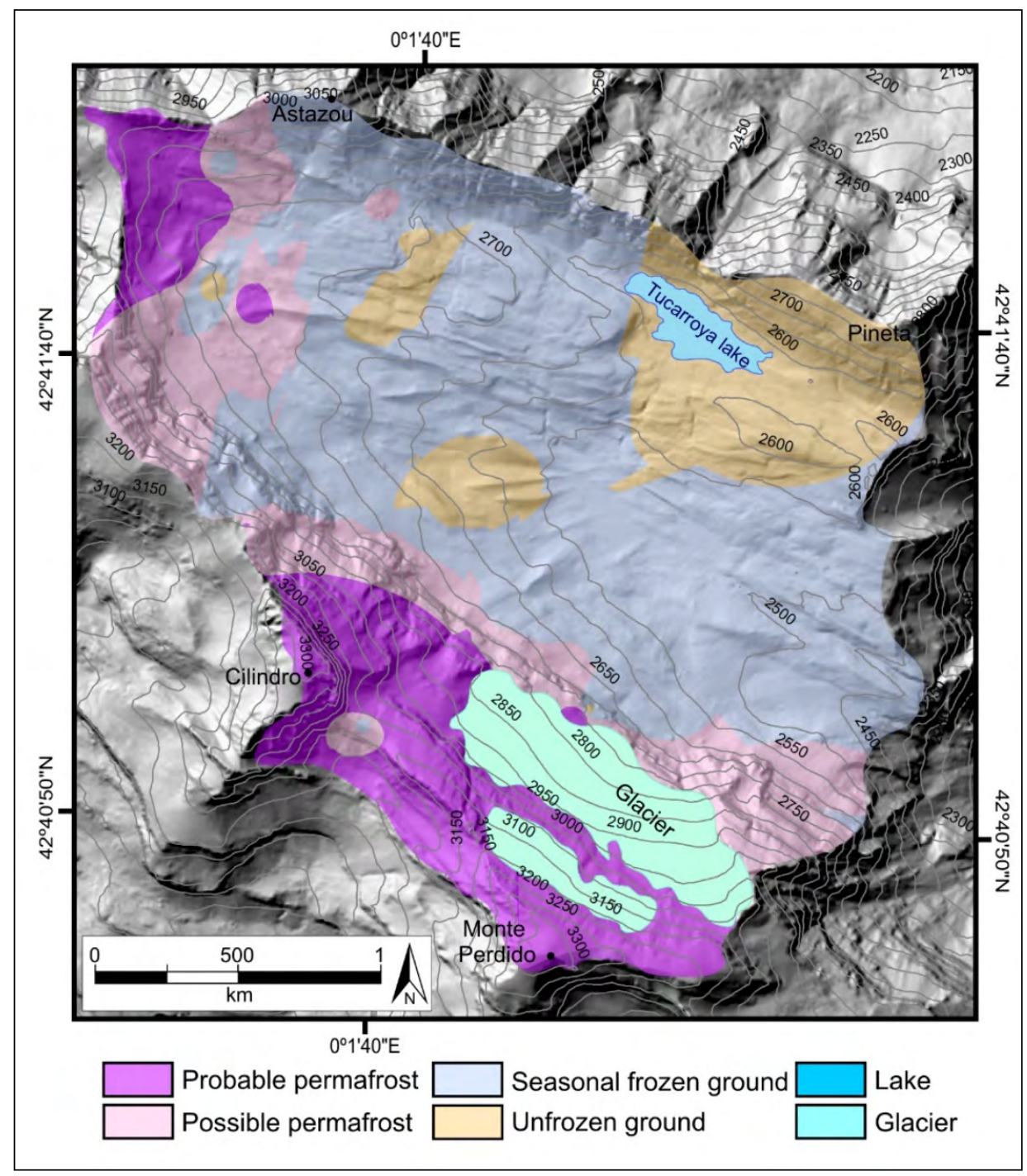

Figure 5. Ground environments of the Tucarroya.

Some periglacial landforms as patterned ground, are located on areas with unfrozen ground and SFG, showing a disequilibrium with the present-day morphoclimatic conditions. Landforms are inherited of ancient climate conditions and processes are inactive. So, a marginal periglacial environment can be recognized in the low areas of Tucarrroya, as it has been showed in the Alps (Delaloye, 2004). The marginal conditions can be related to the environmental changes caused by the elevation of the atmospheric isotherms derived from climate change. If the present- 
day climate evolution is kept, changes in the permafrost and SFG environments can be presumed, and marginal areas, where the atmospheric and ground thermal state are in disequilibrium, will be wider.

\section{Conclusions}

The resulting map presents four different ground periglacial environments. The identification of the main periglacial processes and landforms has been the starting point; and the incorporation of GTS and BTS measurements, and the topoclimatic factors -solar radiation, slope, orientation, and altitude- by mean of GIS techniques, have allowed represent the ground periglacial environment. Frost weathering, nivation, gelifluction and cryoturbation are particularly linked to the presence of frozen ground. They were used to detect the occurrence of frozen ground. BTS and GTS measurements and topoclimatic factors provided the spatially distributed data to be represented on a map.

The map includes four ground environments, "unfrozen ground with frost activity", "Seasonally frozen ground", "Possible permafrost", and "Probable permafrost". All of them are representative of the different ground thermal regimes and geomorphic processes, and they have a high interest for ecological and hydrological studies.

The fall in ground temperatures with altitude, together with aspect and snowcover thickness and duration, drive the location and distribution of periglacial environments. The three environments with frozen ground are ordered in altitudinal belts. Frozen ground is mainly located over $2800 \mathrm{~m}$ a.s.1., although SFG can be found from $2500 \mathrm{~m}$ a.s.1. The most widespread environment is SFG, occupying wide areas of the bottom of the valley and south-facing slopes, on an altitudinal rank around $820 \mathrm{~m}$. Potential mountain permafrost environments are very small in size. Possible permafrost is located over $2760 \mathrm{~m}$ a.s.l. and probable permafrost over $2880 \mathrm{~m}$ a.s.l. in the surroundings of ice-patches, steep slopes, debris, moraines and cliffs, always in north-facing areas.

Maps of periglacial environments can be a useful tool to predict future changes associated with global changes in the high mountain, and to improve habitat management in National Parks. The map of frozen ground in Tucarroya and Monte Perdido covers a small area $(570 \mathrm{Ha})$, but it exhibits a large variety of cryosphere environments, including glaciers, ice caves, mountain permafrost, SFG and unfrozen ground. It illustrates the great diversity and complexity of high-altitude areas subject to deglaciation and warming processes. These should also be considered due to their unique thermal and hydrological conditions, which are favourable to potential biological recolonization, the presence of endemisms and extremophile species of ecological and scientific interest. The map can be of use in studies on geomorphology, but also in those on biological, hydrological, ecological and environmental change to earth science and biology researchers and also NPA managers. The map reveals high geodiversity that brings value and exceptionality to Tucarroya and Monte Perdido, located in a unique natural area, the Ordesa-Monte Perdido National Park or the Sobrabe Geopark. 


\section{Acknowledgements}

This research was funded by I+D+I projects CGL2015-68144-R, HidroibernieveCGL2017-82216-R (MINECO of Spanish government-FEDER) and Geoparque Sobrarbe-Comarca del Sobrabe (R- ADM15/57).

\section{References}

Barrère, P. 1952. Évolution méchanique et nivation sur les versants calcaires de la haute montagne pyrénéenne. Pirineos 24, 201-213.

Boyé, M. 1952. Gélivation et cryoturbation dans le massif du Mont Perdu (Pyrénées Centrales). Pirineos 23, 5-29.

Bockheim, J.G. 2015. Global Distribution of Cryosols with Mountain Permafrost: An Overview. Permafrost and Periglacial Processes 26 (19) 1-12. https://doi.org/10.1002/ppp.1830.

Boeckli, L., Brenning, A., Gruber, S., Noetzli, J. 2012. Permafrost distribution in the European Alps: calculation and evaluation of an index map and summary statistics. The Cryosphere 6, 807-820.

Chueca, J., Julián, A. 2010. Caracterización térmica del suelo en el circo del Aneto (Pirineo central aragonés): cartografía de variaciones estacionales. In: J.J. Blanco, M.A. de Pablo, M. Ramos (Eds.). Ambientes periglaciares, permafrost y variabilidad climática. Universidad de Alcalá, Alcalá de Henares, pp. 55-60.

Delaloye, R. 2004. Contribution à l'étude du pergélisol de montagne en zone marginale. GeoFocus $10,240 \mathrm{pp}$.

Evans, D.J.A., Ria, K., Orton, C. 2017. Periglacial geomorphology of summit tors on Bodmin moor, Cornwall, SW England. Journal of Maps 13, 342-349. https://doi.org/10.1080/17445 64720171308283.

Funk, M., Hoelzle, M. 1992. A model of potential direct solar radiation for investigating occurrences of mountain permafrost. Permafrost and Periglacial Processes 3, 39-142. https:// doi.org/10.1002/ppp.3430030211.

Garcia-Ruiz, J.M., Marti-Bono, C. 2001. Mapa geomorfológico del Parque Nacional de Ordesa y Monte Perdido. Organismo Autónomo de Parques Nacionales, Madrid, 106 pp.

García-Ruiz, J.M., Palacios, D., De Andrés, N., Valero, B.L., López-Moreno, J.I., Sanjuán, Y. 2014. Holocene and Little Ice Age Glacial activity in the Marboré Cirque, Monte Perdido Massif, Central Spanish Pyrenees. The Holocene 24 (11), 1439-1452. https://doi. org/10.1177\%2F0959683614544053.

González-García, M. 2013. La alta montaña periglaciar en el Pirineo Central Español: procesos, formas y condiciones ambientales. Tesis doctoral, Universidad de Málaga, Málaga.

González-García, M, Serrano, E, González-Trueba, J.J. 2014. Elaboración de un mapa térmico de suelos en la alta montaña de la Maladeta (Pirineo central). In: A. Gómez-Ortíz, F. Salvador, M. Oliva, M. Salvá, (Eds.). Avances, métodos y técnicas en el estudio del periglaciarismo. Universitat de Barcelona, Barcelona, pp. 277-286.

Gruber, S., Haeberli, W. 2009. Mountain permafrost. In: R. Margesin (Ed.) Permafrost Soils. Springer-Verlag, Berlin, pp. 33-44. https://doi.org/10.1007/978-3-540-69371-0.

Gruber, S., Hoelzle, M. 2001. Statistical modelling of mountain permafrost distribution: local calibration and incorporation of remotely sensed data. Permafrost and Periglacial Processes 12 (1), 69-77. https://doi.org/10.1002/ppp.374.

Haeberli, W., Noetzli, J., Arenson, L., Delaloye, R., Gätner-Roer, I., Gruber, S., Isaksen, K., Kneisel, K., Krautblatter, M., Phillips, M. 2010. Mountain permafrost: development and challenges of a young research field. Journal of Glaciology 56 (200), 1043-1058. https://doi. org/10.3189/002214311796406121. 
Heginbottom, J.A. 2002. Permafrost mapping: a review. Progress in Physical Geography 26, 623642. https://doi.org/10.1191\%2F0309133302pp355ra.

Hoelzle, M. 1996. Mapping and modelling of mountain permafrost distribution in the Alps. Norwegian Journal of Geography 50, 11-15. https://doi.org/10.1080/00291959608552347.

Hoelzle, M., Haeberli, W., Keller, F. 1993. Aplication of BTS measurements for modelling mountains permafrost distribution. The $6^{\text {th }}$ International Conference on Permafrost, Beijing, China, pp. 272-277.

Janke, J.R. 2005. Modeling past and future alpine permafrost distribution in the Colorado Front Range. Earth Surface Processes and Landforms 30 (12), 1495-1508. https://doi.org/10.1002/esp.1205.

Keller, F. 1992. Automated mapping of mountain permafrost using the program PERMAKART within the geographical information system ARC/INFO. Permafrost and Periglacial Processes 3 (2), 133-138. https://doi.org/10.1002/ppp.3430030210.

Keller, F., Frauenfelder, R., Gardaz, J.M., Hoezle, M., Kneisel, C., Lugon, R., Phillips, M., Reynard, E., Wenker, L. 1998. Permafrost map of Switzerland. $7^{\circ}$ International Permafrost Conference. Université de Laval, Yellowknife, pp. 557-562.

Lambiel, C. 2006. Le pergélisol dans les terrains sédimentaires à forte déclivité : distribution, régime thermique et instabilités. $\mathrm{PhD}$ Thesis, Université de Lausanne, $260 \mathrm{pp}$.

Lambiel, C., Pieracci, K. 2008. Permafrost distribution in Talus Slopes located within the Alpine Periglacial Belt, Swiss Alps. Permafrost and Periglacial Processes 19, 293-304. https://doi. org/10.1002/ppp.624.

Leunda, M., González-Sampériz P, Gil-Romera G., Aranbarri J., Moreno, A., Oliva-Urcia B., Sevilla, M., Valero, B. 2017. The Late-Glacial and Holocene Marboré Lake sequence (2,612 $\mathrm{m}$ a.s.1., Central Pyrenees, Spain): Testing high altitude sites sensitivity to millennial scale vegetation and climate variability. Global and Planetary Change 157, 214-231. https://doi. org/10.1016/j.gloplacha.2017.08.008.

López-Moreno, J.I., Revuelto, J. Rico, I., Chueca-Cía, J., Julián, A., Serreta, A., Serrano, E., Vicente-Serrano, S., Azorin-Molina, C., Alonso-González, E., García-Ruiz, J.M. 2016. Thinning of the Monte Perdido Glacier in the Spanish Pyrenees since 1981. The Cryosphere 10 (2), 681-694. https://doi.org/10.5194/tc-10-681-2016.

López-Moreno J.I., Alonso-González, E., Montserrat, O., del Río L.M., Otero, J., Lapazaran, J., Luzi, G., Dematteis, N., Serreta, A., Rico, I., Serrano, E., Bartolomé, M., Moreno, A., Buisan, S., Revuelto, J. 2019. Ground-based remote sensing techniques for diagnosis of the current state and recent evolution of the Monte Perdido Glacier, Spanish Pyrenees. Journal of Glaciology 65 (249), 85-100. https://doi.org/10.1016/j.gloplacha.2017.08.008.

Lugon, R., Delaloye, R., Serrano, E., Reynard, E., Lambiel, C., González Trueba, J.J. 2004. Permafrost and Little Ice Age relationships, Posets massif, Central Pyrenees, Spain. Permafrost and Periglacial Processes 15, 207-220. http://doi.org/10.1002/ppp.494.

Magnin, F., Josnin, J.Y., Ravanel, L., Pergaud, J., Pohl, B., Deline, P. 2017. Modelling rock wall permafrost degradation in the Mont Blanc massif from the LIA to the end of the $21^{\text {st }}$ century. The Cryosphere 11, 1813-1834. https://doi.org/10.5194/tc-11-1813-2017.

Martínez de Pisón, E, Arenillas, M. 1988. Los glaciares actuales del Pirineo Español. In: La nieve en el Pirineo español. MOPU, Madrid, pp. 29-98.

Martínez de Pisón, E., Arozena, M.E., Serrano, E. 2001. Las unidades de paisajes naturales de la reserva de la biosfera Ordesa-Viñamala: estudio geográfico. Comité Español del Programa MAB, Madrid.

Martín-Moreno, R. 2006. Estudio Comparativo de formas y procesos glaciares y periglaciares desde la Pequeña Edad del Hielo: altas latitudes noruegas (Spitsbergen y Jotunheimen) $y$ altas altitudes españolas (Pirineos, Sistema Central y Teide). PhD Thesis, Universidad Autónoma de Madrid, Madrid. 
Nicolás, P. 1981. Morfología del circo de Tucarroya (Macizo del Monte Perdido, Pirineo aragonés). Cuadernos de Investigación Geográfica 7, 51-80. https://doi.org/10.18172/cig.884

Oliva, M., Serrano, E., Gomez-Ortiz, A.G., Gonzalez-Amuchastegui, M.J., Nieuwendam, A., Palacios, D., Perez-Alberti, A.P., Pellitero, R., Ruiz, J., Valcarcel, M., Vieira, G. Antoniades, D.2016. The periglaciation of the Iberian Peninsula. Spatial and temporal variability. Quaternary Science Reviews 137, 176-199. https://doi.org/10.1016/j.quascirev.2016.02.017.

Oliva, M., Ruiz-Fernández, J., Barriendos, M., Benito, G., Cuadrat, J.M., García-Ruiz, J.M., Giralt, S., Gómez-Ortiz; A., Hernández, A., López-Costas, O., López-Moreno, J.I., López-Sáez, J.A., Martínez-Cortizas, A., Moreno, A., Prohom, M., Saz, M.A., Serrano, E., Tejedor, E., Trigo, R., Valero, B., Vicente-Serrano, S. 2018. The Little Ice Age in the Iberian Mountains. Earth-Science Reviews 177, 175-208.

Oliva, M, Žebre., M., Guglielmin, M., Hughes, P.D., Çiner, A., Vieira, G., Bodin, X., Andrés, N., Colucci, R.R., García-Hernández, C., Mora, C., Nofre, J., Palacios, D., Pérez-Alberti, A., Ribolini, A., Ruiz-Fernández, J., Sarıkaya, M.A., Serrano, E., Urdea, P., Valcárcel, M., Woodward, J.C., Yıldırım, C. 2018. Permafrost conditions in the Mediterranean Region since the Last Glaciation. Earth-Science Reviews 185, 397-436. https://doi.org/10.1016/j. earscirev.2018.06.018.

PNOA (2015). Ortofotos digitales de los vuelos PNOA, CC-BY 4.0 ign.es. Available in: http:// centrodedescargas.cnig.es/CentroDescargas/index.jsp.

Rico, I., Izaguirre, E., Serrano, E., López-Moreno, J.I. 2017. Current glacier area in the Pyrenees: an updated assessment. Pirineos 72, e029. https://doi.org/103989/Pirineos 2017172004.

Ríos, L.M., Galera, J.M., Baretino, D. 1989. Mapa Geológico de España 1:50.000, Hoja no 146 Bujaruelo. ITGE, Madrid.

Serrano, E., Agudo, C., Martínez De Pisón, E. 1999. Rock glaciers in the Pyrenees. Permafrost and Periglacial Processes 10, 101-106. https://doi.org/10.1002/(SICI)10991530(199901/03)10:1\%3C101::AID-PPP308\%3E3.0.CO;2-U.

Serrano, E., Agudo, C., Delaloye, R., González-Trueba, J.J. 2001. Permafrost distribution in the Posets massif, Central Pyrenees. Norwegian Journal of Geography 55, 245-252. http://doi. org/10.1080/00291950152746603.

Serrano, E., Morales, C., González-Trueba, J.J., Martín-Moreno, R. 2009. Cartografía del permafrost de montaña en los Pirineos españoles. Finisterra 87, 45-54. https://doi. org/10.18055/Finis1376.

Serrano, E., González Trueba, J.J., Sanjosé, J.J. 2011. Dinámica, evolución y estructura de los glaciares rocosos de los Pirineos. Cuadernos de Investigación Geográfica 37 (2), 145-170. https://doi.org/10.18172/cig.1260.

Serrano, E., Gómez-Lende, M., Belmonte, A., Sancho, C., Sánchez-Benítez, J, Bartolomé, M., Leunda, M., Moreno, A., Hivert, B. 2018. Ice caves in Spain. In: A. Persiou, S.E. Lauritzen (Eds.), Ice Caves. Elsevier, Amsterdam, pp. 625-656.

Serrano, E., Martín-Moreno, R. 2018. Surge glaciers during the Little Ice Age in the Pyrenees. A controversial dynamics. Cuadernos de Investigación Geográfica 44, 213-244. https://doi. org/10.18172/cig.3399.

Serrano, E., Oliva, M., González-García, M., López-Moreno, J.I., González-Trueba, J.J., MartínMoreno, R., Gómez-Lende, M., Martín-Díaz, J., Nofre, J., Palma, P. 2018. Post-Little Ice Age paraglacial processes and landforms in the high Iberian Mountains: a review. Land Degradation and Development 29 (11), 4186-4208. https://doi.org/10.1002/ldr3171.

Serrano, E., Sanjosé, J.J., Gómez-Lende, M., López-Moreno, J.I., Pisabarro, A, MartínezFernández, A. 2019. Periglacial environments and frozen ground in the Central Pyrenean high mountain area: Ground thermal regime and distribution of landforms and processes. Permafrost and Periglacial Processes 30 (4), 292-309. https://doi.org/10.1002/ppp.2032. 
Serrano, E., López-Moreno, J.I., Gómez-Lende, M., Pisabarro, A., Martín-Moreno, R., Rico, I., Alonso-González, E. 2020. Relationship between frozen ground and periglacial processes in temperate high mountains: a case study at Monte Perdido-Tucarroya area (the Pyrenees, Spain). Journal of Mountains Science, 17. https://doi.org/10.1007/s11629-019-5614-5.

Valero, B., Oliva, B., Moreno, A., Rico, M., Mata, P., Salazar, A., Rieradeval, M., García-Ruiz, J.M., Chueca, J., González-Sampériz, P., Pérez, A., Salabarnada, A., Pardo, A., Arruebo Muñio, T., Sancho, C., Barreiro, F., Bartolomé, M., García-Prieto, E., Gil-Romera, G., López-Merino, L., Sevilla-Callejo, M., Tarrats, P. 2013. Dinámica glacial, clima y vegetación en el Parque Nacional de Ordesa y Monte Perdido durante el Holoceno. In: Memorias de Proyectos de investigación en Parques Nacionales: 2009-2012. OAPN, Madrid, pp. 7-37.

Van Everdingen, R.O. 1978. Frost mounds at Bear Rock, near Fort Norman, N.W.T., 1975-1976. Canadian Journal of Earth Sciences 15, 263-276. https://doi.org/10.1139/e78-027.

Zhang, Y., Olthof, I., Fraser, R.H., Wolfe, S.A. 2014. A new approach to mapping permafrost and change incorporating uncertainties in ground condition and climate projections. The Cryosphere 8 (6), 2177-2194. https://doi.org/10.5194/tcd-8-1895-2014. 